\title{
PENINGKATAN KEMAMPUAN PENALARAN SISWA MELALUI PEMBELAJARAN DISCOVERY LEARNING PADA MATERI LIMAS
}

\section{(IMPROVING STUDENT'S ABILITY ABILITY THROUGH DISCOVERY LEARNING LEARNING IN LIMAS MATERIALS)}

\author{
Fahmi Abdul Halim ${ }^{1}$, Dini Riza Rustiyanti ${ }^{2}$ \\ ${ }^{1}$ Dosen Prodi Pend. Matematika STKIP PGRI Lumajang, \\ Email: fahmi_abdul_halim@yahoo.com \\ ${ }^{2}$ Mahasiswa Prodi Pendidikan Matematika STKIP PGRI Lumajang, \\ Email: dini.riza.ae@gmail.com
}

\begin{abstract}
Abstrak
Penelitian ini dilatarbelakangi dari hasil observasi awal di SMP Negeri 5 Lumajang kelas VIII D yang menunjukkan bahwa mayoritas siswa sulit menguasai matematika. Selain itu siswa juga lemah dalam hal kemampuan penalaran, hal ini berdasarkan hasil jawaban siswa terhadap pretest mengenai penalaran yang diberikan oleh peneliti. sebanyak 52\% siswa saat pretest memberikan jawaban yang salah sehingga penalaran siswa perlu ditingkatkan. Solusi dari permasalahan di atas yaitu dengan menggunakan pembelajaran discovery learning. Tujuan penelitian ini adalah untuk mendeskripsikan pelaksanaan pembelajaran discovery learning yang dapat meningkatkan penalaran siswa kelas VIII D SMP Negeri 5 Lumajang. Tahap penelitian dimulai dengan perencanaan, tindakan, pengamatan, dan refleksi. Dari penelitian diperoleh bahwa langkah-langkah pembelajaran discovery learning yang dapat meningkatkan penalaran siswa sebagai berikut: (1) Stimulation, (2) Problem Statement, (3) Data Collection, (4) Data Processing, (5) Verification (Pembuktian), (6) Generalization (penenarikan kesimpulan). Hasil dari penelitian menunjukkan bahwa pembelajaran discovery learning dapat meningkatkan penalaran siswa.
\end{abstract}

Kata Kunci : Pembelajaran Discovery Learning, Penalaran

\begin{abstract}
This research was motivated by the results of preliminary observations in state yunior high school 5 Lumajang gradeVIII D which showed that the majority of students had difficulty mastering mathematics. In addition, students are also weak in terms of reasoning abilities, this is based on the results of student answers to the pretest regarding the reasoning given by the researcher. As many as $52 \%$ of students at the pretest gave a wrong answer so that the students' reasoning needed to be improved. The solution to the above problems is by using discovery learning. The purpose of this study is to describe the implementation of discovery learning that can improve the reasoning of grade VIII D students of state yunior high school 5 Lumajang. The research phase begins with planning, action, observation, and reflection. From the research, it was found that the steps of discovery learning that can improve student reasoning are as follows: (1) Stimulation, (2) Problem Statement, (3) Data Collection, (4) Data Processing, (5) Verification, (6) Generalization. The results of the study indicate that discovery learning can improve student reasoning.
\end{abstract}


Keywords: Discovery learning, Reasoning

\section{PENDAHULUAN}

Pendidikan merupakan hal yang sangat penting dalam kehidupan kita untuk meningkatkan sumber daya manusia yang unggul dan kompetitif pada era globalisasi saat ini (Ilahi, 2012). Salah satu cara pengembangkan pedidikan adalah dengan pembelajaran matematika. NCTM (2000) mengatakan bahwa ada lima standar pembelajaran matematik yaitu: kemampuan pemecahan masalah (problem solving), kemampuan penalaran (reasoning and proof), kemampuan komunikasi (communication), kemampuan koneksi (connection), dan kemampuan representasi (representation)". Ratnaningsih (dalam Muharom, 2014) juga mengatakan bahwa pembelajaran matematika selain dapat mengembangkan cara berpikir siswa pembelajaran matematika juga dapat mengembangkan kemampuan penalaran. Penalaran adalah proses pencapaian kesimpulan logis berdasarkan fakta dan sumber yang relevan. Penalaran adalah proses berpikir yang dilakukan dengan suatu cara untuk menarik kesimpulan (Sumarmo dalam Sulistiawati, 2016).

Berdasarkan observasi awal yang dilakukan oleh peneliti di SMP Negeri 5 Lumajang kelas VIII D, banyak siswa yang sulit menguasai materi Limas. Siswa lebih cenderung mencari jawaban matematika dengan cara cepat tanpa menanamkan konsep yang benar. Di samping itu kemampuan penalaran siswa juga masih rendah. Hal ini ditunjukkan oleh hasil jawaban siswa dari pretest tentang penalaran yang diberikan oleh peneliti, banyak siswa yang memberikan jawaban tidak tepat. Di kelas VIII D, sebanyak 16 siswa dari 31 siswa memberikan jawaban yang salah atau sebesar $52 \%$ dari hasil pretest tersebut tidak memuaskan. Dalam hal ini kemampuan penalaran siswa perlu ditingkatkan. Peneliti memilih Limas, dikarenakan pada materi sebelumnya siswa sudah belajar mengenai konsep teorema Pythagoras sehingga ada kesinambungan materi dengan penelitian ini. Selain itu, materi ini cukup bervariasi dan cakupannya juga luas. Materi ini juga pernah diajarkan di sekolah dasar pada materi bangun ruang sehingga para siswa telah memiliki konsep dasar pada materi ini. Seperti soal yang ditampilkan dibawah ini:

\section{Sebuah piramida alas nya berbentuk segitiga siku-siku dengan sisinya alasnya adalah 5 meter, 12 meter, 13 meter dan tingginya adalah 20 meter. Berapa meter kubikkah material yang dibutuhkan untuk membangun piramida tersebut dan biaya yang diperlukan untuk membuat piramida tersebut jika setiap 4 meter kubiknya dibutuhkan biaya $\$ 10.000$ ?}

Gambar 1. Studi Pendahuluan Kemampuan Penalaran

Soal tersebut mendorong siswa agar menggunakan rumus dalam menghitung volume piramida yang berbentuk limas segitiga siku-siku. Sebelum menemukan volume piramida tersebut, terlebih dahulu siswa harus menemukan luas alas piramida tersebut. Karena bentuk alasnya adalah segitiga siku-siku dan telah diketahui sisi-sisi alasnya maka dari sini teorema Pythagoras memberikan konstribusi penting dalam solusi soal ini. Jadi ada kesinambungan dengan materi lain. Selain itu, soal tersebut juga memberikan pertanyaan biaya untuk membuat 
piramida tersebut. Menggunakan rumus, berpikir, dan mencari solusi merupakan bagian dari kemampuan penalaran. Selanjutnya akan dipaparkan sampel jawaban siswa dalam mengerjakan soal studi pendahuluan kemampuan penalaran.

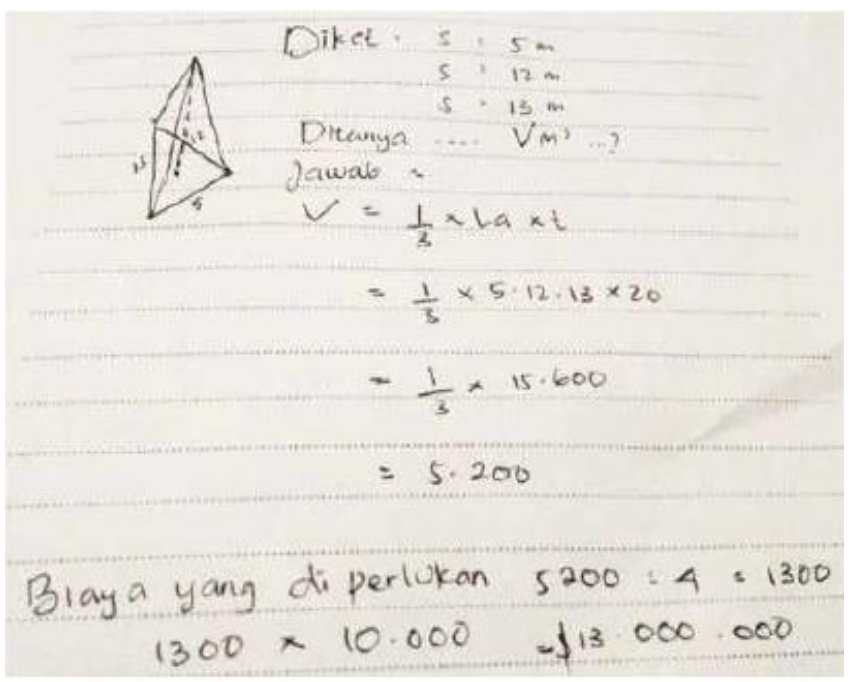

Gambar 2. Jawaban Siswa N-15

Gambar 2 menunjukkan bahwa siswa N-15 memberikan jawaban untuk soal dengan cara yang sistematis namun konsep rumus luas alasnya kurang tepat. Selain itu, seharusnya adalah menggunakan konsep teorema Pytahgoras, namun cara mencari biayanya sudah tepat.

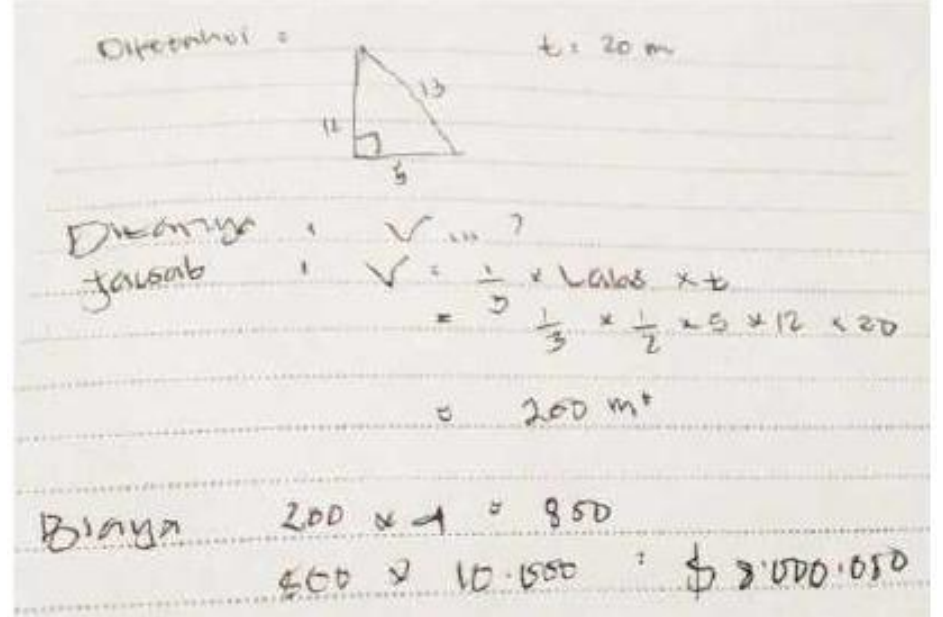

Gambar 3. Jawaban Siswa N-20

Gambar 3 menunjukkan bahwa siswa N-20 memberikan jawaban untuk soal dengan cara yang sistematis dan konsep mencari volume limas sudah tepat. Namun, untuk mencari besar biayanya konsep siswa N-20 kurang memahami seharusnya dibagi 4 bukan dikali 4 .

Salah satu Model pembelajaran yang dapat meningkatkan kemampuan penalaran matematika adalah pembelajaran Discovery Learning (Istiana, 2015). Discovery Learning adalah salah satu pembelajaran dimana siswa terlibat langsung dalam kegiatan belajar-mengajar, sehingga siswa mampu menggunakan proses mentalnya untuk menemukan suatu konsep atau teori yang sedang 
dipelajari. Dengan kata lain, landasan pemikiran yang mendasari pembelajaran ini bisa lebih mudah ditransformasikan dalam menghadapi kompleksitas kehidupan (Mohammad, 2012).

Dari uraian diatas maka peneliti melakukan penelitian tindakan kelas dengan judul: Peningkatan Kemampuan Penalaran Siswa Melalui Pembelajaran Discovery Learning Pada Materi Limas. Tujuan dalam penelitian ini adalah untuk mendeskripsikan Peningkatan Kemampuan Penalaran Siswa Melalui Pembelajaran Discovery Learning Pada Materi Limas.

\section{KAJIAN TEORI \\ Penalaran}

Secara etimologis matematika berarti ilmu pengetahuan yang diperoleh dengan bernalar (Suherman dalam Hariyanti, 2010). Dalam hal ini bukan berarti ilmu lain tidak diperoleh melalui penalaran, akan tetapi dalam matematika lebih menekankan aktivitas dalam dunia rasio (penalaran), sedangkan dalam ilmu lain lebih menekankan pada hasil observasi atau eksperimen di samping penalaran. Hudojo (dalam Hariyanti, 2010) menyatakan matematika sebagai ilmu yang menelaah bentuk-bentuk atau struktur-struktur yang abstrak, Objek penelaahan matematika tidak sekedar kuantitas, tetapi lebih dititik beratkan kepada hubungan, pola, bentuk dan struktur.

Penalaran adalah proses pencapaian kesimpulan logis berdasarkan fakta dan sumber yang relevan. Penalaran adalah proses berpikir yang dilakukan dengan suatu cara untuk menarik kesimpulan (Sumarmo dalam Sulistiawati, 2016). Ribowo (2015) menyatakan bahwa proses pembelajaran matematika dengan pembelajaran Discovery Learning dapat meningkatnya penalaran dan hasil belajar matematika.

\section{Discovery Learning}

Hamalik (dalam Mohammad, 2012) berpendapat bahwa discovery adalah proses pembelajaran yang menitikberatkan pada mental intelektual para siswa dalam memecahkan berbagai persoalan yang dihadapi, sehingga menemukan suatu konsep atau generalisasi yang dapat diterapkan di lapangan. Discovery (penemuan) adalah proses mental ketika siswa mengasimilasi suatu konsep atau suatu prinsip (Hamdani, 2010).

Discovery Learning adalah salah satu pembelajaran yang memungkinkan para siswa terlibat langsung dalam kegiatan belajar-mengajar, sehingga mampu menggunakan proses mentalnya untuk menemukan suatu konsep atau teori yang sedang dipelajari. Dengan kata lain, landasan pemikiran yang mendasari pembelajaran ini bisa lebih mudah ditransformasikan dalam menghadapi kompleksitas kehidupan (Mohammad, 2012).

Sutman (dalam Rahmalia, 2014) menyebutkan bahwa Langkah-langkah pembelajaran Discovey Learning adalah sebagai berikut :

1. Stimulation (Stimulasi/Pemberian Rangsangan)

Pada tahap ini siswa dihadapkan pada sesuatu permasalahan yang menimbulkan keinginantahuan siswa untuk menyelidiki sendiri. Tahap ini berfungsi untuk menyediakan kondisi interaksi belajar yang dapat mengembangkan dan membantu siswa dalam mengeksplorasi bahan pelajaran atau materinya. 
2. Problem Statement (Pernyataan/Identifikasi Masalah)

guru memberi kesempatan kepada siswa untuk mengidentifikasi sebanyak mungkin agenda-agenda masalah yang relevan dengan bahan pelajaran, kemudian salah satunya dipilih dan dirumuskan dalam bentuk hipotesis (jawaban sementara atas pertanyaan masalah), sedangkan menurut permasalahan yang dipilih itu selanjutnya harus dirumuskan dalam bentuk pertanyaan, atau hipotesis, yakni pernyataan (statement) sebagai jawaban sementara atas pertanyaan yang diajukan.

3. Data Collection (Pengumpulan Data)

Pada tahap ini siswa diberi kesempatan untuk mengumpulkan berbagai informasi yang relevan dengan membaca literatur, mengamati objek, wawancara dengan narasumber, melakukan ujicoba, dan sebagainya. Konsekuensi dari tahap ini adalah siswa belajar secara aktif untuk menemukan sesuatu yang berhubungan dengan permasalahan yang dihadapi, dengan demikian secara tidak disengaja siswa menghubungkan masalah dengan pengetahuan yang telah dimiliki.

4. Data Processing (Pengolahan Data)

Pengolahan data merupakan kegiatan mengolah data dan informasi yang telah diperoleh para siswa baik melalui wawancara, observasi, dan sebagainya, lalu ditafsirkan. Semua informai hasil bacaan, wawancara, observasi, dan sebagainya, semuanya diolah, diacak, diklasifikasikan, ditabulasi, bahkan bila perlu dihitung dengan cara tertentu serta ditafsirkan pada tingkat kepercayaan tertentu.

5. Verification (Pembuktian)

Pada tahap ini siswa melakukan pemeriksaan secara cermat untuk membuktikan benar atau tidaknya hipotesis yang ditetapkan tadi dengan temuan alternatif, dihubungkan dengan hasil data processing. Verification bertujuan agar proses belajar akan berjalan dengan baik dan kreatif jika guru memberikan kesempatan kepada siswa untuk menemukan suatu konsep, teori, aturan atau pemahaman melalui contoh-contoh yang ia jumpai dalam kehidupannya.

6. Generalization (Penarikan Kesimpulan)

Tahap ini adalah proses menarik kesimpulan yang dapat dijadikan prinsip umum dan berlaku untuk semua kejadian atau masalah yang sama, dengan memperhatikan hasil verifikasi. Berdasarkan hasil verifikasi maka dirumuskan prinsip-prinsip yang mendasari generalisasi.

Pembelajaran ini menekankan untuk menemukan konsep sendiri, melakukan penyelidikan sendiri, melakukan pembuktian terhadap suatu dugaan yang dibuat sendiri dan mencari jawaban atas pertanyaan teman atau gurunya. Peranan guru adalah sebagai fasilitator di dalam kelas untuk membantu siswa dalam menemukan suatu konsep materi.

Pembelajaran discovery learning adalah untuk menggali potensi siswa dan belajar menemukan sutu konsep matematika di dalam kegiatan belajar mengajar matematika, karena dengan penerapan pembelajaran discovery learning diharapkan dapat meningkatkan kemampuan penalaran matematika siswa (Istiana, 2015). 


\section{METODE}

Jenis penelitian ini adalah penelitian tindakan kelas (PTK). Subjek penelitian adalah siswa kelas VIII D SMP Negeri 5 Lumajang Tahun Ajaran 2016/2017. Tahap penelitian melalui siklus yang terdiri dari perencanaan, tindakan, pengamatan, dan refleksi. Kegiatan merencanakan adalah menyusun perangkat pembelajaran dan instrumen penelitian, kemudian memvalidasinya, serta melakukan tes awal dan membentuk kelompok belajar. Kegiatan tindakan adalah menerapkan pembelajaran Discovery Learning yang dapat meningkatkan penalaran siswa pada materi limas. Kegiatan mengamati dilakukan oleh dua orang pengamat secara bersamaan. Kegiatan merefleksi dilakukan berdasarkan hasil pengamatan, kemudian mengambil kesimpulan apakah kemampuan penalaran siswa pada materi limas sudah meningkat atau belum.

Sumber data dalam penelitian ini berasal dari: (a) hasil observasi lembar pengamatan aktivitas guru dan siswa, (c) hasil tes awal dan tes akhir dan (d) wawancara. Sedangkan untuk analisis data dilakukan dengan menggunakan teknik-teknik analisis data kualitatif yang didalamnya melibatkan kegiatan penelaahan seluruh data yang telah dikumpulkan, mereduksi data dan memverifikasi data serta membuat kesimpulan dari data tesebut.

Pada saat proses pembelajaran di kelas peneliti melakukan langkahlangkah pembelajaran Discovery Learning sebagai berikut: pada tahap stimulation guru memberikan beberapa pengenalan awal tentang materi Limas dan mengingatkan kembali materi yang telah dipelajari serta materi-materi yang berhubungan dengan materi Limas. Pada tahap problem statement, guru memberikan pernyataan dan pertanyaan-pertanyaan serta mengidentifikasi masalah yang diberikan, contohnya yaitu menyebutkan benda-benda yang menyerupai bangun limas dan lain-lain. Pada tahap data collection dan data processing, siswa mengumpulkan data-data atau jawaban hasil pemikiran dan diskusi mereka bersama kelompok untuk menyelesaikan masalah dan menjawab pertanyaan, sementara guru sebagai fasilitator bagi siswa. Pada tahap verification, guru dan siswa membahas dan membuktikan hasil jawaban untuk mencari kebenarannya. Pada tahap generalization, guru dan siswa membuat kesimpulan dari materi yang telah dipelajari.

Kriteria keberhasilan dari penelitian ini sebagai berikut: 1). Kemampuan penalaran siswa dikatakan meningkat jika setelah pembelajaran dilakukan kemampuan meningkat siswa meningkat 20\% dan sebanyak minimal $70 \%$ dari keseluruhan siswa memperoleh skor minimal 75 pada tes akhir. 2) Rata-rata hasil pengamatan aktivitas guru dan aktivitas siswa dalam pembelajaran Discovery Learning minimal berada pada kategori baik, yaitu $75 \%$.

\section{HASIL DAN PEMBAHASAN \\ Hasil Penelitian}

1) Tahap perencanaan yaitu (a) penyusunan RPP, (b) penyusunan LKS, (c) penyusunan lembar pengamatan, (d) penyusunan instrumen tes, (e) penyusunan rubrik penilaian kemampuan penalaran, (g) penyusunan lembar wawancara, dan (h) penyusunan lembar validasi.

2) Tahap pelaksanaan yaitu Pelaksanaan kegiatan pembelajaran dilaksanakan dalam 4 pertemuan, yaitu: (a) pertemuan pertama tentang jaring-jaring limas segitiga dan luas permukaan limas segitiga, (b) pertemuan kedua tentang 
volume limas segitiga, (c) pertemuan ketiga tentang jaring-jaring limas segiempat dan luas permukaan limas segiempat, dan (d) pertemuan keempat tentang volume limas segiempat.

3) Tahap observasi, dalam penelitian ini terdiri dari 2 observer yaitu 2 teman sejawat. Tugas observer dalam melakukan pengamatan pada tindakan ini berpedoman pada lembar observasi yang telah di sediakan oleh peneliti. Data hasil pengamatan terhadap aktivitas siswa dan guru sebagai berikut:

Tabel 1. Aktivitas Siswa dan Guru dalam Pembelajaran Discovery Learning

\begin{tabular}{llllll}
\hline Kegiatan & & $\begin{array}{l}\text { Observer 1 } \\
\text { persentase }\end{array}$ & $\begin{array}{l}\text { Observer 2 } \\
\text { persentase }\end{array}$ & $\begin{array}{l}\text { Rata-Rata } \\
\text { persentase }\end{array}$ & kategori \\
\hline Pertemuan I & $\begin{array}{l}\text { Aktivitas guru } \\
\text { Aktivitas }\end{array}$ & $51 \%$ & $81 \%$ & $66 \%$ & $\begin{array}{l}\text { Cukup } \\
\text { siswa }\end{array}$ \\
$\begin{array}{l}\text { Aktivitas guru } \\
\text { Pertemuan II }\end{array}$ & $72 \%$ & $78 \%$ & $67 \%$ & Cukup \\
& $\begin{array}{l}\text { Aktivitas } \\
\text { siswa }\end{array}$ & $69 \%$ & $81 \%$ & $76,5 \%$ & Baik \\
Pertemuan & Aktivitas guru & $88 \%$ & $91 \%$ & $89 \%$ & Baik \\
III & $\begin{array}{l}\text { Aktivitas } \\
\text { siswa }\end{array}$ & $81 \%$ & $88 \%$ & $84,5 \%$ & $\begin{array}{l}\text { Sangat } \\
\text { Baik } \\
\text { Baik }\end{array}$ \\
Pertemuan & Aktivitas guru & $84 \%$ & $88 \%$ & $86 \%$ & $\begin{array}{l}\text { Sangat } \\
\text { IV }\end{array}$ \\
& $\begin{array}{l}\text { Aktivitas } \\
\text { Siswa }\end{array}$ & $84 \%$ & $88 \%$ & $86 \%$ & $\begin{array}{l}\text { Sangat } \\
\text { Baik }\end{array}$ \\
\hline
\end{tabular}

4) Tahap refleksi, Refleksi dilakukan untuk menentukan tindakan telah berhasil atau perlu dilakukan perbaikan. Dari hasil tes akhir tindakan siklus didapatkan data sebagai berikut:

Tabel 2. Rekapitulasi Nilai Tes Awal dan Tes Akhir Siklus

\begin{tabular}{llllc}
\hline Nilai Siswa & \multicolumn{2}{l}{ Tes Awal } & \multicolumn{2}{l}{ Tes Akhir Siklus } \\
\hline Nilai $\geq 75$ & 16 & $51 \%$ & 23 & $75 \%$ \\
Nilai $<75$ & 15 & $49 \%$ & 8 & $25 \%$ \\
\hline
\end{tabular}

Pada hasil tes akhir siklus diatas dapat diperoleh data bahwa siswa yang memperoleh nilai $\geq 75$ adalah sebanyak 23 dari 31 siswa yang mengikuti tes akhir siklus, dan siswa yang memperoleh nilai < 75 adalah sebanyak 15 siswa dari 31 siswa yang mengikuti tes akhir siklus. Hal ini dapat dikatakan bahwa siswa tuntas belajar sebesar $75 \%$ dan siswa yang tidak tuntas sebesar $25 \%$.

\section{Pembahasan}

Pembelajaran discovery learning dalam penelitian ini adalah pembelajaran yang bertujuan meningkatkan penalaran siswa dengan langkah-langkah pembelajaran sebagai berikut:

1. Stimulation (Stimulasi/Pemberian Rangsangan), Pada tahap ini guru mengingatkan kembali materi yang berkaitan dengan limas yang telah 
dipelajari pada bab sebelumnya, guru juga menginformasikan tujuan tujuan pembelajaran. Hal ini sesuai dengan pendapat Ruseffendi (2001) yang menyatakan bahwa dengan terumuskannya tujuan pembelajaran maka pembelajaran akan lebih terarah.

2. Problem Statement (Pernyataan/Identifikasi Masalah)

Pada tahap ini guru memberi kesempatan kepada siswa untuk mengidentifikasi sebanyak mungkin agenda-agenda masalah yang relevan dengan bahan pelajaran, kemudian salah satunya dipilih dan dirumuskan dalam bentuk hipotesis (jawaban sementara atas pertanyaan masalah), sedangkan menurut permasalahan yang dipilih itu selanjutnya harus dirumuskan dalam bentuk pertanyaan, atau hipotesis, yakni pernyataan (statement) sebagai jawaban sementara atas pertanyaan yang diajukan.

3. Data Collection (Pengumpulan Data)

Pada tahap ini guru memberikan kesempatan krepada siswa untuk mengumpulkan berbagai informasi yang relevan dengan membaca literatur, mengamati objek, wawancara dengan narasumber, melakukan ujicoba untuk menemukan sesuatu yang berhubungan dengan permasalahan yang dihadapi, dengan demikian secara tidak disengaja siswa menghubungkan masalah dengan pengetahuan yang telah dimiliki (Syah dalam Ayadiya, 2014).

4. Data Processing (Pengolahan Data)

Pada tahap pengolahan data ini merupakan kegiatan mengolah data dan informasi yang telah diperoleh para siswa baik melalui wawancara, observasi, dan sebagainya, lalu ditafsirkan. Semua informai hasil bacaan, wawancara, observasi, dan sebagainya, semuanya diolah, dan diklasifikasikan.

5. Verification (Pembuktian)

Pada tahap ini siswa melakukan pemeriksaan secara cermat untuk membuktikan benar atau tidaknya hipotesis yang ditetapkan tadi dengan temuan alternatif, dihubungkan dengan hasil data processing. Verification menurut Bruner (dalam Mufadlilah, 2015) bertujuan agar proses belajar akan berjalan dengan baik dan kreatif jika guru memberikan kesempatan kepada siswa untuk menemukan suatu konsep, teori, aturan atau pemahaman melalui contoh-contoh yang ia jumpai dalam kehidupannya.

6. Generalization (Penarikan Kesimpulan)

Tahap ini adalah proses menarik kesimpulan yang dapat dijadikan prinsip umum dan berlaku untuk semua kejadian atau masalah yang sama, dengan memperhatikan hasil verifikasi. Berdasarkan hasil verifikasi maka dirumuskan prinsip-prinsip yang mendasari generalisasi (Syah dalam Mufadlilah, 2015).

Peningkatan penalaran siswa dapat diketahui melalui aktivitas selama proses pembelajaran dan tes akhir akhir. Dari analisa data hasil nilai tes akhir siswa menunjukkan bahwa persentase siswa tuntas belajar pada tes akhir siklus mencapai $75 \%$, Persentase ketuntasannya tersebut mengalami peningkatan sebesar $24 \%$. Sesuai dengan data tersebut, maka pembelajaran yang dilakukan pada penelitian ini dikatakan berhasil karena telah mencapai kriteria yang ditetapkan. Berdasarkan hasil wawancara juga diperoleh fakta bahwa siswa 
merasa senang selama pembelajaran berlangsung karena siswa diberi kebebasan kebebasan dalam berpikir dan menyampaikan ide dan pendapatnya.

\section{SIMPULAN}

Berdasarkan terlaksananya pembelajaran dengan model pembelajaran discovery learning yang telah dideskripsikan pada hasil dan pembahasan penelitian, maka dapat diambil kesimpulan sebagai berikut: Langkah- langkah pembelajaran discovery learning yang dapat meningkatkan penalaran siswa yaitu: (1) memberikan stimulation yaitu memberikan rangsangan dengan menyediakan kondisi interaksi belajar yang dapat mengembangkan dan membantu siswa dalam mengeksplorasi bahan pembelajaran, (2) Problem Statement (Pernyataan/Identifikasi Masalah) adalah mengidentifikasi sebanyak mungkin agenda-agenda masalah yang relevan dengan bahan pelajaran, (3) Data Collection (pengumpulan data) adalah pengumpulkan berbagai informasi yang relevan dengan mengikuti petunjuk bahan pembelajaran, membaca literatur, mengamati objek, melakukan ujicoba, dan sebagainya, (4) Data Processing (Pengolahan Data) adalah mengolah data yang diperoleh kemudian diolah, diklasifikasikan, dan dihitung dengan cara tertentu, (5) Verification (Pembuktian) adalah memverifikasi hasil jawaban, berfungsi untuk membuktikan benar atau tidaknya dugaan sementara yang ditetapkan tadi dengan temuan alternatif, dihubungkan dengan hasil pengolahan data. (6) Generalization (generalisasi data) yaitu proses menarik kesimpulan yang dapat dijadikan prinsip umum dan berlaku untuk semua kejadian atau masalah yang sama, dengan memperhatikan hasil verifikasi.

Pembelajaran Discovery Learning dapat meningkatkan kemampuan penalaran siswa kelas VIII D SMP Negeri 5 Lumajang pada materi Limas tahun pelajaran 2016/2017. Hal ini dapat ditunjukkan dari hasil analisis kemampuan penalaran siswa mengalami peningkatan sebesar 25\%. Berdasarkan hal tersebut hasil penelitian pada materi Limas siswa kelas VIII D di SMP Negeri 5 Lumajang semester genap tahun pelajaran 2016/2017 menggunakan pembelajaran Discovery Learning diperoleh hasil, mengalami peningkatan.

Dari hasil penelitian saran untuk tindak lanjut bagi peniliti lainnya yang akan melakukan penelitian selanjutnya yaitu: yang pertama untuk dapat mengembangkan model pembelajaran yang digunakan dan salah satunya adalah Discovery Learning yang dapat digunakan untuk meningkatkan kemampuan penalaran siswa.

\section{DAFTAR RUJUKAN}

Ayadiya, Naila. 2014. Penerapan Model Pembelajaran Discovery Learning Dengan Scientific Approach Untuk Meningkatkan Ketrampilan Proses Sains Siswa SMA. Skripsi tidak diterbitkan. Semarang: Fakultas Matematika dan Ilmu Pengetahuan Alam Universitas Negeri Semarang.

Hariyanti. 2010. Upaya Meningkatkan Kemampuan Penalaran Matematika Siswa Kelas VII C SMP Negeri 2 Depok Sleman dalam Pembelajaran Matematika Melalui Pendekatan Investigasi. Skripsi tidak terbitkan. Yogyakarta: Fakultas Matematika dan Ilmu Pengetahuan Alam Universitas Negeri Yogyakarta.

Hamdani. 2010. Strategi Belajar Mengajar. Bandung: CV. Pustaka Setia. 
Ilahi, Mohammad Takdir. 2012. Pembelajaran Discovery Strategy \& Mental Vocation Skill. Jakarta: Diva Press.

Istiana, Galuh Arika \& Catur, Agung Nugroho. 2015. Penerapan Model Pembelajaran Discovery Learning Untuk Meningkatkan Aktivitas Dan Prestasi Belajar Pokok Bahasan Larutan Penyangga Pada Siswa Kelas XI IPA Semester II SMA Negeri 1 Ngemplak Tahun Pelajaran 2013/2014. Jurnal Pendidikan Kimia (JPK), (Online), Volume 04, Nomor 02, Hal. 6573 (http://jurnal.fkip.uns.ac.id/index.php/kimia diaskes 15 Okober 2016).

Mohammad, Iqbal. 2012. Kemampuan Penalaran Matematis Siswa Dalam Menemukan Rumus Barisan Aritmatika Berbantuan Alat Peraga Sederhana. Jurnal Pendidikan. (Online), Vol. 2 No. 2 (https://goglescolar.com diaskes 25 Okober 2016).

Mufadlilah, Ainur Rohman. 2015. Kefektifan Discovery Learning Dengan Pendekatan Saintifik Berbantuan Mathematics Circuit Untuk Meningkatkan Kemampuan Representasi Matematik. Skripsi tidak diterbitkan. Semarang: Fakultas Matematika dan Ilmu Pengetahuan Alam Universitas Negeri Semarang.

Muharom, Tria. 2014. Pengaruh Pembelajaran Dengan Model Kooperatif Tipe Student Teams Achievement Division (STAD) Terhadap Kemampuan Penalaran dan Komunikasi Matematik Siswadi SMK Negeri Manonjaya Kabupaten Tasikmalaya. Jurnal Pendidikan dan Keguruan. (Online), Vol. 1 No. 1, artikel 1, (https://goglescolar.com diaskes 20 Okober 2016).

NCTM / National Council of Teachers of Mathematics. 2000. Principles and Standards for School Mathematics. United States of America: Association Drive.

Qorri'ah. 2011. Penggunaan Metode Guided Discovery Learning Untuk Meningkatkan Pemahaman Konsep Siswa Pada Pokok Bahasan Bangun Ruang Sisi Lengkung. Skripsi tidak terbitkan. Jakarta: Fakultas Ilmu Tarbiyah Dan Keguruan UIN Syarif Hidayatullah.

Rahmalia, Yuli. 2014. Efektivitas Model Discovery Learning Untuk Peningk Hasil Belajar Siswa Kelas X pada Kompetensi Dasar Analisis Rangkaian Kemagnetan di SMK 1 Pundong. Skripsi tidak diterbitkan. Yogyakarta: Fakultas Teknik Universitas Negeri Yogyakarta.

Ribowo. 2015. Peningkatan Penalaran Dan Hasil Belajar Matematika Melalui Pembelajaran Discovery Learning Pada Siswa Kelas VII Semester Genap Smp Al-Islam Pakis Tahun 2014/2015. Skripsi tidak diterbitkan. Surakarta: Fakultas Keguruan dan Ilmu Pendidikan Universitas Muhammadiyah Surakarta.

Ruseffendi, E. T, Pengantar kepada Membantu Guru Mengembangkan Kompetensinya dalam Pengajaran Matematikau ntuk Meningkatkan CBSA, Tarsito: Bandung, 1991.

Setiawati, Bayu Urip. 2005. Pelajaran Matematika Untuk SMP Kelas VIII. Depok: Arya Duta.

Sulistiawati, dkk. 2016. Peningkatan Kemampuan Penalaran Matematis Menggunakan Desain Didaktis Berdadasarkan Kesulitan Belajar pada Materi Luas dan Volume Limas. JPPM, (Online), Volume 09, Nomor 01, (https://goglescolar.com diaskes 01 Okober 2016). 